
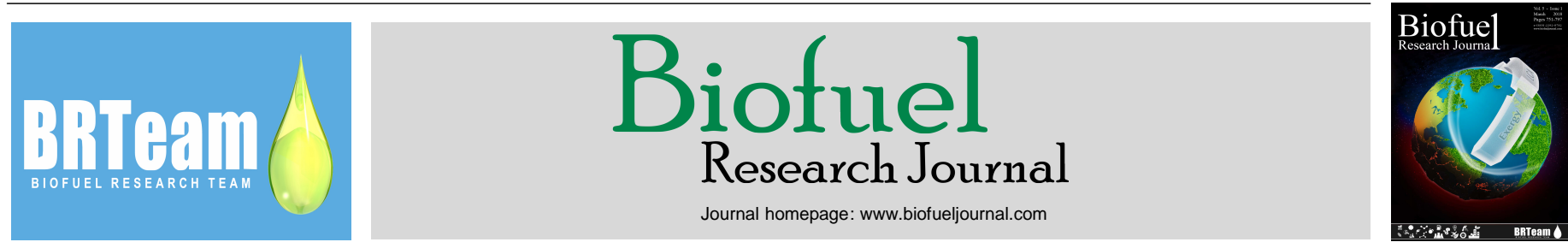

Review Paper

\title{
Microalgal biomass pretreatment for bioethanol production: a review
}

Jesús Velazquez-Lucio ${ }^{1,2}$, Rosa M. Rodríguez-Jasso ${ }^{1,2}$, Luciane M. Colla ${ }^{3}$, Aide Sáenz-Galindo ${ }^{4}$, Daniela E. CervantesCisneros ${ }^{1,2}$, Cristóbal N. Aguilar ${ }^{1}$, Bruno D. Fernandes ${ }^{5}$, Héctor A. Ruiz ${ }^{1,2, *}$

${ }^{I}$ Biorefinery Group, Food Research Department, Faculty of Chemistry Sciences, Autonomous University of Coahuila, 25280, Saltillo, Coahuila, Mexico.

${ }^{2}$ Cluster of Bioalcohols, Mexican Centre for Innovation in Bioenergy (Cemie-Bio), Mexico.

${ }^{3}$ Laboratory of Fermentations, Graduate Program in Food Science and Technology, University of Passo Fundo, Campus I, Passo Fundo, Rio Grande do Sul, Brazil.

${ }^{4}$ Department of Organic Chemistry, Faculty of Chemistry Sciences, Autonomous University of Coahuila, 25280 Saltillo, Coahuila, Mexico.

${ }^{5}$ CEB-Centre of Biological Engineering, University of Minho, Campus Gualtar, 4710-057 Braga, Portugal.

\section{HIGHLIGHTS}

$>$ An overview on different aspect of $3^{\text {rd }}$ generation bioethanol producted is presented.

$>$ Different pretreatment methods used for microalgae biomass are reviwed and discussed.

$>$ Different methods for starch and carbohydrates quantification are described.

\section{GRAPHICAL ABSTRACT}

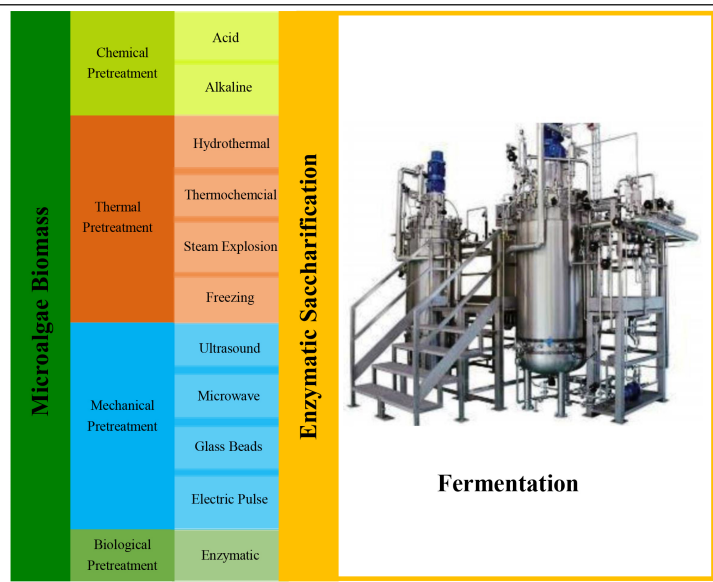

\section{ARTICLE INFO}

\section{Article history:}

Received 28 April 2017

Received in revised form 1 August 2017

Accepted 25 October 2017

Available online 1 March 2018

\section{Keywords:}

Microalgae

Carbohydrates

Bioethanol

Biorefinery

Pretreatment

Biomass

\begin{abstract}
Biofuels derived from microalgae biomass have received a great deal of attention owing to their high potentials as sustainable alternatives to fossil fuels. Microalgae have a high capacity of $\mathrm{CO}_{2}$ fixation and depending on their growth conditions, they can accumulate different quantities of lipids, proteins, and carbohydrates. Microalgal biomass can, therefore, represent a rich source of fermentable sugars for third generation bioethanol production. The utilization of microalgal carbohydrates for bioethanol production follows three main stages: i) pretreatment, ii) saccharification, and iii) fermentation. One of the most important stages is the pretreatment, which is carried out to increase the accessibility to intracellular sugars, and thus plays an important role in improving the overall efficiency of the bioethanol production process. Diverse types of pretreatments are currently used including chemical, thermal, mechanical, biological, and their combinations, which can promote cell disruption, facilitate extraction, and result in the modification the structure of carbohydrates as well as the production of fermentable sugars. In this review, the different pretreatments used on microalgae biomass for bioethanol production are presented and discussed. Moreover, the methods used for starch and total carbohydrates quantification in microalgae biomass are also briefly presented and compared.
\end{abstract}

(c) 2018 BRTeam. All rights reserved.

* Corresponding author at: Tel.: (+52) 8444161238

E-mail address: hector_ruiz_leza@uadec.edu.mx

Please cite this article as: Velazquez-Lucio J., Colla L.M., Rodríguez-Jasso R.M., Sáenz-Galindo A., Cervantes-Cisneros D.E., Aguilar C.N., Fernandes B.D., Ruiz H.A. Microalgal biomass pretreatment for bioethanol production: a review. Biofuel Research Journal 17 (2018) 780-791. DOI: 10.18331/BRJ2018.5.1.5 


\section{Contents}

1. Introduction .....

2. Overview of microalgae biomass .

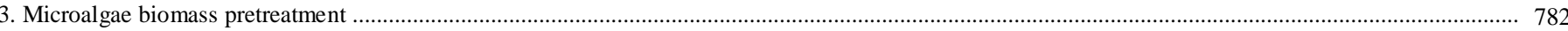

3.1. Enzymatic pretreatment ……………

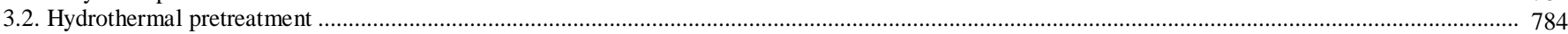

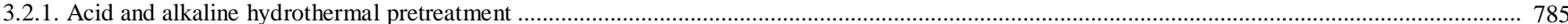

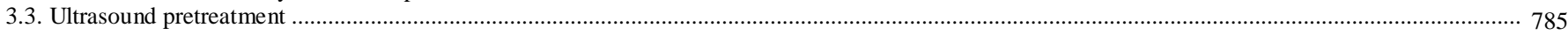

3.4. Microwave pretreatment ………

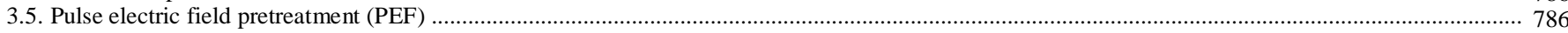

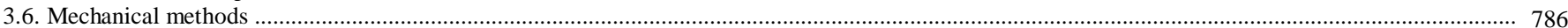

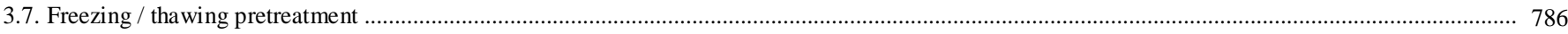

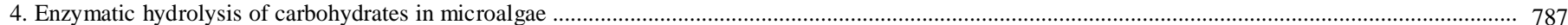

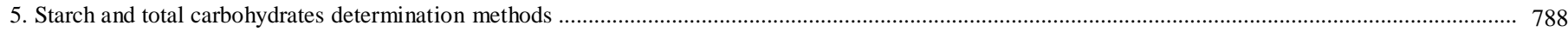

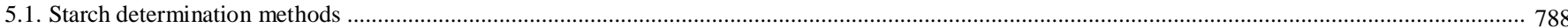

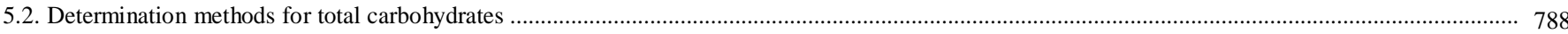

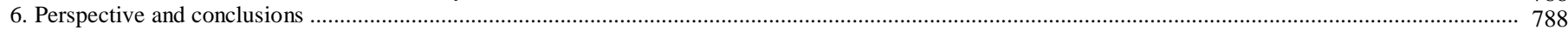

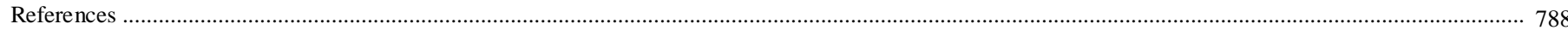

\section{Introduction}

In recent years, the use of petroleum has greatly increased resulting in an eminent depletion of these resources. In addition, fossil fuels produce the major fraction of $\mathrm{CO}_{2}$ that causes the greenhouse effect, resulting in the need to develop new alternative energy sources to meet the global energy demands (Borines et al., 2013). Biofuels are alternatives to reduce the dependence on fossil fuels in a near future, being bioethanol one of the most important choices. According to the Renewable Fuels Association (RFA, 2015), the global production of bioethanol stood at 25,682 million gallons in the year 2015, with the USA (14.806 billion gallons) and Brazil (7.093 billion gallons) as the largest producers in the world. Nowadays, there are two types of gasolineethanol fuel blends for vehicles in the USA, i) E15 defined by the Environmental Protection Agency (USA) as the mixture of gasoline with 10.5 - $15 \%$ ethanol which can be used in conventional vehicles manufactured from 2001 onwards and ii) E85 (or flexible fuel) which is the mixture of ethanolgasoline with high ethanol concentrations ranging between 51-83\%. The latter is used in flexible fuel vehicles, leading to savings in fuel costs and reduced greenhouse gas (GHG) emissions (RFA, 2015; DOE, 2016).

Bioethanol can be produced through different biorefinery-based processes (Laurens et al., 2012). Nevertheless, as the first step, it is always necessary to find renewable raw materials with suitable compositions in terms of carbohydrates. According to the feedstock considered, there are three generations of bioethanol: i) first generation, where bioethanol is produced from human food/animal feed ingredients (e.g., soybean, wheat, rice, corn, sugarcane, etc.); ii) second generation bioethanol from lignocellulosic materials/agro-industrial residues (e.g., corn cob, wheat straw, sugar cane bagasse, agave bagasse, etc.), and iii) third generation bioethanol produced from aquatic biomass (such as cyanobacteria, macroalgae, and microalgae) (SAGARPA, 2011; Carvalho et al., 2013; de Vries et al., 2014; van Ejick et al., 2014; Cuellar-Bermudez et al., 2015). Among these, aquatic biomass especially microalgae biomass (and its application within the biorefinery framework) has been highlighted in recent years owing to its higher potential for bioethanol production. The ability to use solar energy and $\mathrm{CO}_{2}$ on one hand and the capability of certain species to accumulate considerable quantities of starch on the other hand are among the most important advantages of such biomass. The high starch accumulation potential marks microalgae a potentially desirable feedstock for the transformation of starch into glucose and consecutively to ethanol by fermentation processes (Chen et al., 2014a; Kim et al., 2014).

Since starch is produced and retained intracellularly, it is necessary to increase its availability/accessibility to microbial fermentation. Accordingly, several pretreatment methods have been reportedly applied on aquatic biomass such as microalgae to extract the intracellular starch (John et al., 2011). The most common pretreatment methods used for aquatic biomass include, i) hydrothermal extraction, using microwave as unconventional type of heating, ii) ultrasound process, iii) enzymatic hydrolysis, and iv) electric pulses. It should be noted that these pretreatments use different kinds of reagents as catalysts, such as water, acids, bases, and supercritical fluids (Miranda et al., 2012; Cheng et al., 2013; Ho et al., 2013a; Chen et al., 2014a).
This review presents the different pretreatment methods that have been used or can be used in the future for microalgae biomass. In addition, the quantification methods for starch and total sugars as well as the other stages of bioethanol production (enzymatic saccharification) are also discussed.

\section{Overview of microalgae biomass}

Microalgae are photosynthetic microorganisms with a cell size between 2-200 $\mu \mathrm{m}$ and a high capacity for fixing $\mathrm{CO}_{2}$. They can be autotrophic and heterotrophic and are capable of producing large amounts of biomass containing lipids, proteins, or carbohydrates (depending on the species and growth conditions) (Alaswad et al., 2015; Baroukh et al., 2015). From the composition point of view, microalgae are composed mainly of proteins, carbohydrates, lipids, ashes, and acids among other compounds. Lignin is not found in microalgae; and thus, its biomass has the advantage of facilitated pretreatment processing or in another word, facilitated enzymatic hydrolysis of the starch contained (Chen et al., 2014a).

Microalgae are complex organisms and are classified into very diverse group. For instance, based on their structural characteristics, they can be rhizoids or cocoides, may or may not have flagella, and live in colonies or aggregates (Tomaselli, 1997). Their cell wall is mainly composed of cellulose, but it can also include pectin and sulfated polysaccharides. Intracellular starch is found in the plastids, ranging from 20 to $50 \%$. The majority of lipids are found intracellularly with concentrations ranging from 20 to $60 \%$ (Ho et al., 2013b; Chen et al., 2014a). Other components such as proteins can also be found in concentrations between 20 and $50 \%$. The concentration of these biochemical compounds depends on the growth conditions and culture medium in which the microorganisms are cultivated, Table 1 presents a comparison of the composition of different microalgae species.

Microalgae biomass is considered important for producing assorted products such as biofuels, bioactive compounds vitamins (e.g., amino acids and vitamins) for human and/or animal consumption, etc. within the biorefinery concept (Ross et al., 2008; John et al., 2011; Kee and Teong, 2015). For instance, Cyanotech Corp. (USA) is the main producer of Spirulina and owns about 9 ha of production in Hawaii, commercializing Spirulina tablets with prices ranging from USD $87.47-142.82 / \mathrm{Kg}$. The Japanese company Yaeyama Shokusan Co. Ltd. also distributes different products of Chlorella in form of tablets, powder, fine powder, and liquid. They have 10 ha of microalgae production making them important producers of microalgae biomass, with selling prices around $\$ 100.00 / \mathrm{Kg}$ of microalgae powder. There are also other industrial companies in the world producing microalgae including Cyano Biofuels GmbH. (Germany), AlgaFuel, S.A. (Portugal), Oil Fox (Argentina), as well as Algae Food and Fuel (Netherlands). Currently there are over fifty companies that produce some types of aquatic biomass either for use as supplement, additives, colorants, food or bioenergy (Klöck, 2010). 
Table 1.

Composition of different species of microalgae (all results are presented in $\%$ dry matter basis).

\begin{tabular}{lllll}
\hline Biomass & Carbohydrates & Proteins & Lipids & References \\
\hline Chlorella vulgaris & 20.99 & 15.67 & 41.51 & Wang et al. (2013) \\
Spirulina platensis & 30.21 & 13.30 & 48.36 & Jena et al. (2011) \\
Chlorella sorokiniana & 35.67 & 9.90 & 18.81 & Chen et al. (2014b) \\
Nannochloropsis oceanica & 22.70 & 24.80 & 19.10 & Cheng et al. (2014) \\
Scenedesmus obliquus & 13.41 & 4.66 & 30.38 & Chen et al. (2014c) \\
Dunaliella tertiolecta & 21.69 & 2.87 & 61.32 & Shuping et al. (2010) \\
Dunaliella salina & 32.00 & 57.00 & 9.00 & Castrillón et al. (2013) \\
Scenedesmus dimorphus & $21-52$ & $8-18$ & $16-40$ & Castrillón et al. (2013) \\
Chlorococum humicola & 32.50 & - & - & Harun and Danquah (2011a) \\
Chlamydomonas reinhardtii & 22.60 & 64.70 & 12.60 & Mahdy et al. (2014) \\
Spirogyra sp. & $33-64$ & $6-20$ & $11-21$ & Milano et al. (2016) \\
Porphyridiumcruentum & $40-57$ & $28-39$ & $9-14$ & Milano et al. (2016) \\
Dunaliella salina & 85.58 & 8.46 & 11.47 & Pirwitz et al. (2016) \\
\hline
\end{tabular}

\section{Microalgae biomass pretreatment}

In the production of bioenergy from aquatic biomass, as in any types of biorefineries, a very important step is the pretreatment of the raw materials, where the objective is to make available the intracellular compounds such as carbohydrates, proteins, lipids, and added-value compounds such as short chain oligosaccharides, antioxidants, pigments, etc. (Harun et al., 2014; Demuez et al., 2015). The two main objectives for which pretreatment of microalgae biomass is necessary are the breakdown of the cell wall and the modification of the structure of intracellular carbohydrates. The carbohydrate from microalgae can be found in the cell wall in the form of cellulose and in the plastids in the form of starch as the major sugar reserve (Fig. 1). Such information is relevant to select the biomass with the highest sugars content for bioethanol production (Chen et al., 2013). Cell wall is composed of cellulose, pectin (polygalacturonic acid), and sulfated polysaccharides, that can be impregnated with inorganic substances such as calcium carbonate, silica, and magnesium (Castrillón et al., 2013; Chen et al., 2013). It is also composed of two layers, i.e., external and internal cell walls (Fig. 2). The former is formed principally by a matrix of polysaccharides like pectin, agar, alginate, and algaenan polymers; while the latter is composed of pectin, fucans, hemicellulose, and glycoproteins in a microfibrils matrix of cellulose, and traces of fucose, xylose, rhamnose, arabinose, and galactose (Scholz et al., 2014). Depending on the composition, the cell wall can result in more or less rigid structure and therefore, it may be more difficult to break, such is in the case of Chlorella sp. that has a harder wall contrary to those of Scenedesmus sp. and cyanobacteria Arthrospira sp.

As for the starch, it is in the form of semi crystalline granulose particles composed of high molecular weight amylose polymers and highly branched amylopectin (Silva and Bertucco, 2016; Huang et al., 2017). The starch granules in their crystalline form contain smaller amounts of water leading to their greater stability and are therefore, more difficult to hydrolyze by enzymes. Hence, it is necessary to change their structure by gelatinization through chemical, physicochemical, or biological pretreatment methods, or combinations of these (Kuakpetoon and Wang, 2007; Cheng et al., 2013; Ho et al., 2013a; Chen et al., 2014a). Among these are acid, alkaline, or biological pretreatments, as well as alternative methods such as ultrasound, microwave, electric pulses, etc. (Miranda et al., 2012; Zhao et al., 2013). Table 2 compares the different studies performed on pretreatment of microalgae biomass for the extraction and hydrolysis of different compounds (i.e., carbohydrates, proteins, lipids, pigments, etc.). Figure 3 shows a general scheme of the third generation bioethanol production process based on the biorefinery concept.

\subsection{Enzymatic pretreatment}

Compared with various pretreatment methods, enzymatic hydrolysis has been shown promising (Liang et al., 2012; Demuez et al., 2015). The main advantages of the enzymatic hydrolysis are its high specificity, no severe conditions requirements, and that it is easy to carry out at industrial scale. The

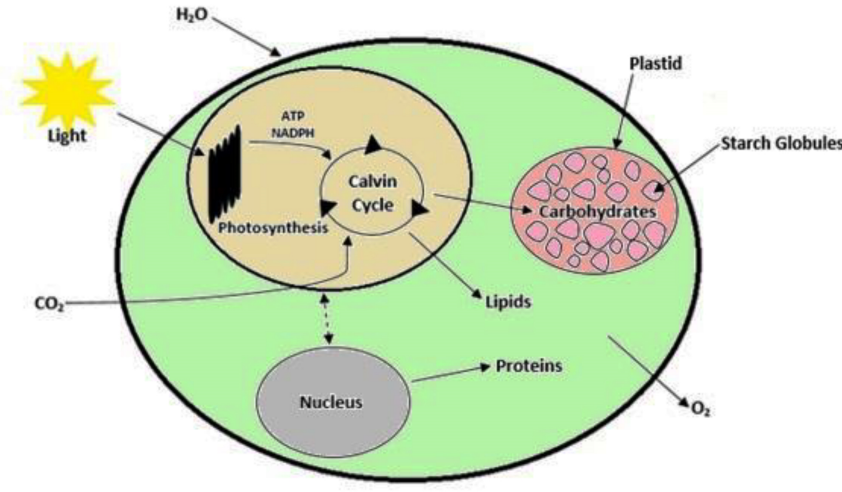

Fig.1. Diagram of starch production in microalgae.

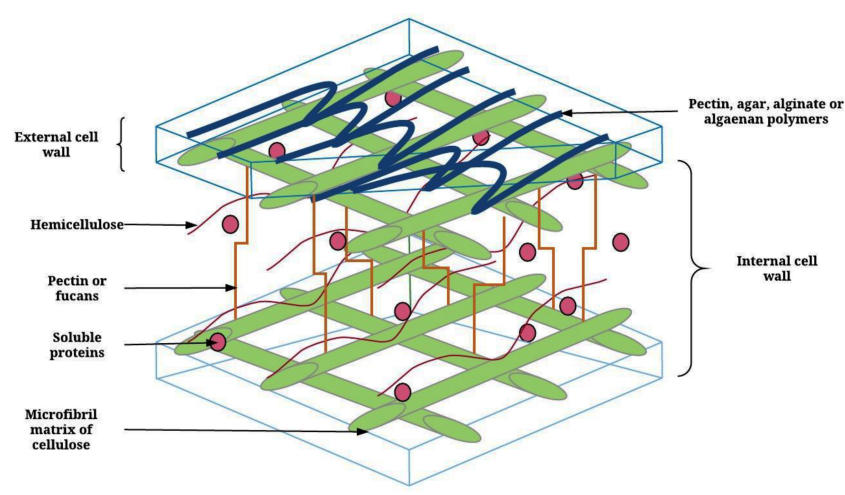

Fig.2. Microalgae cell wall composition.

main disadvantage is the high cost of enzymes used (Günerken et al., 2015). Enzymatic hydrolysis is performed using different enzymes among which cellulases, amylases, and amyloglucosidases are meant to hydrolyze the cell wall polysaccharides. The use of proteases has also been reported to hydrolyze the glycoproteins present in the cell walls of some microalgae 
Table 2.

Different pretreatments of microalgae biomass for extraction of different compounds.

\begin{tabular}{|c|c|c|c|c|}
\hline Biomass & $\begin{array}{l}\text { Pretreatment } \\
\text { method }\end{array}$ & Conditions & Extracted compounds & References \\
\hline Scenedesmus sp. & Hydrothermal & $\begin{array}{l}\text { Water } \\
1: 13(\mathrm{w} / \mathrm{v}) \\
147^{\circ} \mathrm{C} \\
40 \mathrm{~min}\end{array}$ & Glucose & Yuan et al. (2016) \\
\hline $\begin{array}{l}\text { Mix of microalgae } \\
\text { (Scenedesmus, Chlorella, Ankistrosdemus, } \\
\text { Micromonas, Chlamydomonas) }\end{array}$ & Acid hydrolysis & $\begin{array}{l}\mathrm{H}_{2} \mathrm{SO}_{4} 1 \mathrm{M} \\
80-90{ }^{\circ} \mathrm{C} \\
120 \mathrm{~min}\end{array}$ & Carbohydrates & Castro et al. (2015) \\
\hline Scenedesmus obliquus & Enzymatic & $\begin{array}{l}\text { Endogalactouronase } 800 \mathrm{U} / \mathrm{g} \\
\text { Esterase } 3600 \mathrm{U} / \mathrm{g} \\
\text { Protease } 90 \mathrm{U} / \mathrm{g} \\
\mathrm{pH} 6 \\
50{ }^{\circ} \mathrm{C} \\
24 \mathrm{~h}\end{array}$ & Carbohydrates & Ometto et al. (2014) \\
\hline $\begin{array}{l}\text { Scenedesmus obliquus, Scenedesmus } \\
\text { quadricauda, Nitzschia } \mathrm{sp} . \\
\text { Aphanothece } \text { sp. } \\
\text { Desmodesmus spinosus } \\
\text { Nitzschia palea }\end{array}$ & Alkaline-peroxide & $\begin{array}{l}\mathrm{H}_{2} \mathrm{O}_{2} 1-7.5 \%(\mathrm{w} / \mathrm{w}) \\
50{ }^{\circ} \mathrm{C} \\
1 \mathrm{~h}\end{array}$ & Carbohydrates and byproducts & Juárez et al. (2016) \\
\hline Scenedesmus obliquus & Acid hydrolysis & $\begin{array}{l}\mathrm{H}_{2} \mathrm{SO}_{4} 2 \mathrm{~N} \\
120{ }^{\circ} \mathrm{C} \\
30 \mathrm{~min}\end{array}$ & Carbohydrates & Miranda et al. (2012) \\
\hline Chlorococcum sp. & $\begin{array}{l}\text { High pressure } \\
\text { homogenization }\end{array}$ & $\begin{array}{l}65-130 \mathrm{~W} \\
40 \mathrm{kHz} \\
25 \mathrm{~min} \\
500-850 \text { bar } \\
15 \mathrm{~min} \\
\text { Glass beads } 1 \mathrm{~mm} \\
1: 2 \text { or } 1: 3(\mathrm{v} / \mathrm{v}) \\
4 \text { min } \\
\\
\mathrm{H}_{2} \mathrm{SO}_{4} 3-8 \%(\mathrm{v} / \mathrm{v}) \\
120-160{ }^{\circ} \mathrm{C} \\
15-45 \mathrm{~min}\end{array}$ & Carbohydrates & Halim et al. (2012) \\
\hline Synechocystis sp. & $\begin{array}{l}\text { Bead milling } \\
\text { Freezing / thawing }\end{array}$ & $\begin{array}{l}300 \mathrm{~W} \\
20-25 \mathrm{kHz} \\
30 \mathrm{~min} \\
200 \mu \mathrm{L} \text { glass beads } \\
10 \mathrm{~min} \\
\text { cycles } 30 \text { s vortexing } / 30 \mathrm{~s} \text { cooling on ice } \\
3 \text { cycles } 10 \text { min freezing } \\
-80^{\circ} \mathrm{C} \\
5 \text { min thawing } 37^{\circ} \mathrm{C}\end{array}$ & Proteins & 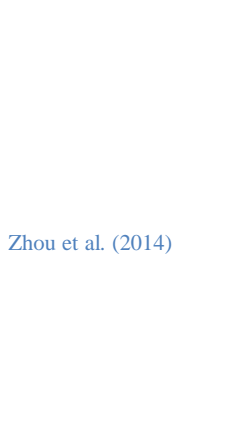 \\
\hline Synechocystis sp. & Pulsed electric field & $\begin{array}{l}17.9-71.7 \mathrm{kWh} / \mathrm{m}^{3} \\
36-54{ }^{\circ} \mathrm{C}\end{array}$ & Cell disruption & Sheng et al. (2011) \\
\hline $\begin{array}{l}\text { Nannochloropsis oculata } \\
\text { Porphyridium cruentum }\end{array}$ & $\begin{array}{l}\text { High pressure } \\
\text { homogenization }\end{array}$ & $\begin{array}{l}10 \mathrm{~mL} \text { compression chamber } \\
50-270 \mathrm{MPa} \\
3{ }^{\circ} \mathrm{C} \\
\text { Glass beads }(0.375,0.625,1.30 \text {, and } 2.15 \\
\mathrm{mm}) \\
\text { Zirconia beads }(0.200,0.600,1.25 \mathrm{~mm}) \\
\text { Rotation speed }(8,10,14 \mathrm{~m} / \mathrm{s}) \\
20^{\circ} \mathrm{C}\end{array}$ & Cell disruption & Montalescot et al. (2015) \\
\hline
\end{tabular}


Table 2.

Continued.

\begin{tabular}{|c|c|c|c|c|}
\hline Biomass & $\begin{array}{l}\text { Pretreatment } \\
\text { method }\end{array}$ & Conditions & Extracted compounds & References \\
\hline Dunaliella tertiolecta & Microwave & $\begin{array}{l}\text { Acetone } \\
50 \mathrm{~W} \\
56{ }^{\circ} \mathrm{C} \\
5 \mathrm{~min}\end{array}$ & Pigments & Pasquet et al. (2011) \\
\hline Ankistrodesmus falcatus & $\begin{array}{l}\text { Pulsed electric field and } \\
\text { solvents }\end{array}$ & $\begin{array}{l}1 \mathrm{~cm} \text { electrode distance } \\
45 \mathrm{kV} / \mathrm{cm} \\
\text { Ethyl acetate / methanol / water }\end{array}$ & Lipids & Zbinden et al. (2013) \\
\hline $\begin{array}{l}\text { Chlorella vulgaris } \\
\text { Neochloris oleoabundan } \\
\text { Tetraselmis suecica }\end{array}$ & Bead milling & $\begin{array}{l}\text { Bead size }(0.3,0.4,0.65,1 \mathrm{~mm}) \\
65 \%(\mathrm{v} / \mathrm{v}) \\
25^{\circ} \mathrm{C}\end{array}$ & Carbohydrates and proteins & Postman et al. (2016) \\
\hline Chlorella vulgaris & Ionic liquid and solvent & $\begin{array}{l}\text { Ionic liquid } \\
1 \mathrm{~h} \text { ambient temperature } \\
\text { Adding hexane mixture } 30 \mathrm{~s} \\
15 \mathrm{~min}\end{array}$ & Cell disruption and lipids & Orr et al. (2016) \\
\hline Chlorella pyrenoidosa & Enzymatic & $\begin{array}{l}\text { Cellulase } 140 \mathrm{mg} / \mathrm{m}^{2} \\
\mathrm{pH} 4.6 \\
50{ }^{\circ} \mathrm{C} \\
24 \mathrm{~h}\end{array}$ & Carbohydrates and lipids & Fu et al. (2010) \\
\hline Oocystis sp. & Hydrothermal & $\begin{array}{l}110 \text { and } 130{ }^{\circ} \mathrm{C} \\
1.2 \text { and } 1.7 \mathrm{bar} \\
15 \text { and } 30 \mathrm{~min}\end{array}$ & Cell disruption & Passos and Ferrer (2015) \\
\hline Nannochloropsis salina & Hydrodynamic cavitation & $\begin{array}{l}\text { Orifice plate with } 13 \text { holes } \\
0.5 \mathrm{~mm} \text { diameter } \\
\text { Upstream / downstream pressures } 4 \text { and } 0.4 \\
\text { bar } \\
26.21 \mathrm{~m} / \mathrm{s} \text { velocity }\end{array}$ & Cell disruption and lipids & Lee and Han (2015) \\
\hline Artrhospira platensis & Pulsed electric field & $\begin{array}{l}15-25 \mathrm{kV} / \mathrm{cm} \\
60-150 \mu \mathrm{s} \\
10-40{ }^{\circ} \mathrm{C}\end{array}$ & Pigments & Martinez et al. (2016) \\
\hline Chlorella vulgaris & Hydrothermal & $\begin{array}{l}\text { Water } \\
140,160,80^{\circ} \mathrm{C} \\
3,6 \text {, and } 10 \text { bar } \\
10-20 \text { min }\end{array}$ & Compounds solubilisation & Mendez et al. (2014) \\
\hline
\end{tabular}

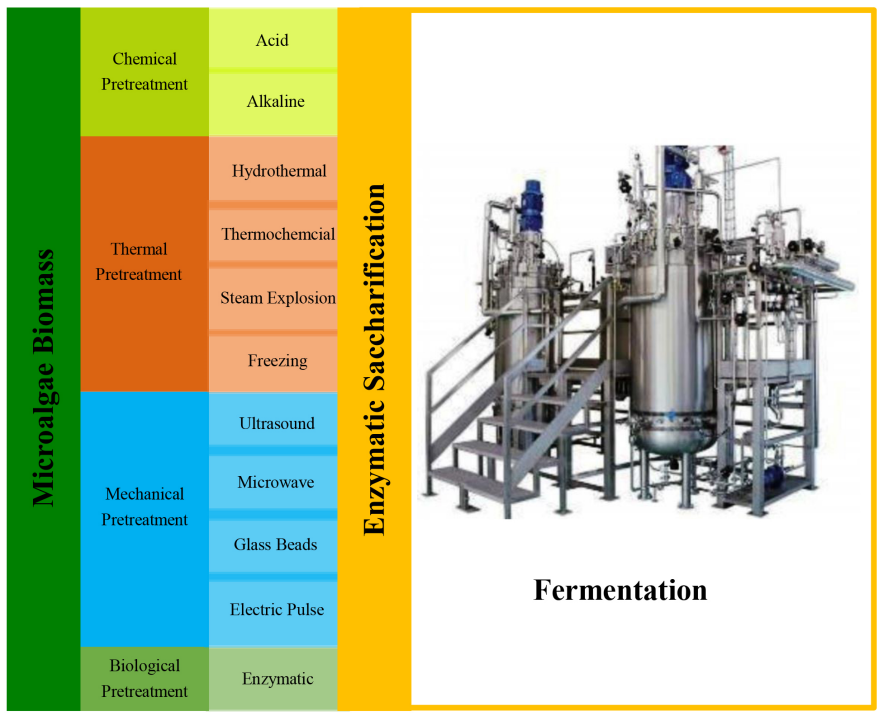

Fig.3. General scheme for $3^{\text {rd }}$ generation pretreatments of bioethanol production. species (Günerken et al., 2015; Pirwitz et al., 2016), resulting in more efficient cell lysis and extraction of target compounds. Liang et al. (2012) used a mixture of neutral and alkaline proteases to promote cell degradation. For the conversion of the polymers present in the cell wall of microalgae, endo- $\beta$ - $(1,4)$-D-glucanase is needed to break the cellulose matrix and the cellulosic linkages, exo- $\beta$ - $(1,4)$-D-glucanase to hydrolyze cellulose into smaller oligosaccharides, and $\beta$-glucosidase to degrade glycosidic bonds into glucose and maltose. Zheng et al. (2016) reported the use of a mixture of cellulases along with different kinds of polymers to enhance the hydrolytic effect of the enzymes by protecting their structure leading to their longer lifetime without alterations. It is important to mention that depending on the type of microalgae, its cell wall may or may not be permeable to other compounds, whereby specific enzymes are not often required to break the cell wall since these (the enzymes) can reach up intracellular carbohydrates. Table 3 tabulates different enzymes used in the degradation of microalgae cell wall.

\subsection{Hydrothermal pretreatment}

Hydrothermal processing is an alternative method to break down microalgae cell walls and to gelatinize the intracellular starch. This technology is also used for pretreatment of both agro-industrial residues (wheat straw, sugarcane bagasse, softwoods, etc.) and aquatic biomass (seaweed). Temperatures ranging from $60-180{ }^{\circ} \mathrm{C}$ and short reaction times below $60 \mathrm{~min}$ are used in this method. Moreover, in this pretreatment, acids, 
Table 3.

Enzymes used in microalgae cell wall degradation.

\begin{tabular}{|c|c|c|c|c|}
\hline Microalgae species & Enzymes & Conditions & Saccharification rate & References \\
\hline Chlorella vulgaris & $\begin{array}{l}\text { Cellulase } \\
\text { Pectinase } \\
\text { Xylanase } \\
\beta \text {-glucosidase } \\
\text { Amylase } \\
\text { Chitinase } \\
\text { Lysozyme } \\
\text { Sulfatase }\end{array}$ & $\begin{array}{l}\text { Cellulase }(0.122 \mathrm{FPU} / \mathrm{mg}) ; \text { Pectinase }(240 \\
\mathrm{IU} / \mathrm{mg} \text { protein); Amy lase }(16 \mathrm{FAU} / \mathrm{mL}) ; \\
\beta \text {-glucosidase }(10 \mathrm{U} / \mathrm{mL}) ; \text { Xylanase }(100 \\
\mathrm{U} / \mathrm{mL}) ; \text { Chitinase }(0.2 \mathrm{U} / \mathrm{mL}) ; \\
\text { Lysozyme }(4000 \mathrm{U} / \mathrm{mL}) ; \text { Sulfatase }(50 \\
\mathrm{U} / \mathrm{mL}) \\
50^{\circ} \mathrm{C} \text { and } \mathrm{pH} 4.8 \text { for } 72 \mathrm{~h}\end{array}$ & $79 \%$ & Kim et al. (2014) \\
\hline $\begin{array}{l}\text { Chlorella vulgaris } \\
\text { Chlamydomonas reinhardtii }\end{array}$ & $\begin{array}{l}\text { Glucanase } \\
\text { Protease }\end{array}$ & $\begin{array}{l}\text { Glucanase }(0.3 \mathrm{~mL} / \mathrm{g} \text { biomass }) \\
\text { Protease }(0.2 \mathrm{~mL} / \mathrm{g} \text { biomass }) \\
50{ }^{\circ} \mathrm{C} \text { and } \mathrm{pH} 4.5 \text { for } 5 \mathrm{~h}\end{array}$ & $86-96 \%$ & Mahdy et al. (2014) \\
\hline Chlorella sorokiniana & $\begin{array}{l}\text { Cellulases } \\
\text { Amylases }\end{array}$ & $\begin{array}{l}\text { Celluclast } 1.5 \mathrm{~L}(60 \mu \mathrm{L} / 3 \mathrm{~g} \text { biomass }) \text {; } \\
\text { Novozyme } 188(30 \mu \mathrm{L} / 3 \text { g biomass }) \text {; } \\
55^{\circ} \mathrm{C} \text { and } \mathrm{pH} 4.5 \text { for } 72 \mathrm{~h}\end{array}$ & $100 \%$ & Hernández et al. (2015) \\
\hline Dunaliella tertiolecta & Amy loglucosidase & $0.4 \mathrm{~mL}$ enzyme $/ \mathrm{g}$ biomass; $55^{\circ} \mathrm{C} \mathrm{pH} 5.5$ & $80.9 \%$ & Lee et al. (2013) \\
\hline Chlamydomonas reinhardtii & $\begin{array}{l}\alpha \text {-amylase } \\
\text { Amyloglucosidase }\end{array}$ & $\begin{array}{l}120 \mathrm{KNU} / \mathrm{g}(300 \mathrm{AGU} / \mathrm{mL}) \text {; } \\
50-65^{\circ} \mathrm{C} \text { and } \mathrm{pH} 4.5-5.5 \text { for } \\
10-60 \mathrm{~min}\end{array}$ & $56 \%$ & Choi et al. (2010) \\
\hline
\end{tabular}

alkalis or only water can be used as reaction catalyst (Chen et al., 2013; Ruiz et al., 2013a and 2015). Using only water as catalyst for biomass pretreatment presents great benefits and has raised great interest in recent years due to the inexistence of toxic waste, no need to neutralize the treated samples, being thus considered as an environmentally friendly process (Hu et al., 2011). However, it is necessary to perform the process at high temperature and pressure values and as a result, hydrothermal pretreatment requires the use of specific equipment that can lead to increased production costs. Some new technologies (ultrasound, microwave, electric pulse, etc.) could also be used in combination to further enhance cell wall disruption resulting in a more efficient pretreatment with lower energy costs and higher recovery of target compounds. Concerning the structural modification of starch, Rubens and Heremans (2000) reported that as temperature and pressure were increased, a better gelatinization was induced, but increasing these parameters to much higher levels could lead to unfavorable outcomes, i.e., the degradation of starch granules.

Different studies have reported on the use of hydrothermal treatments for preparation and solubilization of organic matters and cellular rupture of aquatic biomass. For instance, Passos et al. (2015) reported the use of a hydrothermal treatment at temperatures between $110-130{ }^{\circ} \mathrm{C}$. Mendez et al. (2014) evaluated more severe conditions with temperatures ranging between $140-180$ ${ }^{\circ} \mathrm{C}$. In a different investigation, Pirwitz et al. (2016) used temperatures up to $200{ }^{\circ} \mathrm{C}$ for more than $60 \mathrm{~min}$ under hydrothermal liquefaction treatment. It is important to note that the treatment used would result in a broad spectrum of other compounds in addition to simple sugars and therefore, it is essential to select the best pretreatment conditions to most efficiently break the cell wall, modify the structure of carbohydrates, and obtain added-value compounds. In better words, since the use of very severe conditions could possibly degrade certain types of compounds like proteins or carbohydrates, thus generating degradation products like acids or furfurals, the choice of pretreatment conditions is critical (Ruiz et al., 2013b).

\subsubsection{Acid and alkaline hydrothermal pretreatment}

Concentrated or diluted acid and alkaline solutions could also be used under hydrothermal conditions resulting in shorter reaction times, lower costs, and higher capacity to hydrolyze polymers and oligosaccharides to monosaccharides (Ometto et al., 2014). Higher concentrations of these chemicals decrease reaction times, avoid the use of enzymes, while the use of low concentrations makes necessary higher temperature and pressure values to achieve favorable hydrolysis efficiencies (Gíro et al., 2010; Lenihan et al., 2010; Talebina et al., 2010). Nevertheless, the use of these chemicals at high temperature involves the formation of high concentrations of degradation compounds. Moreover, these compounds are undesirable for the subsequent fermentation process since they are inhibitory to the microorganisms involved in the process (Duarte et al., 2009; Ruiz et al., 2013c). In addition to these, they can also cause equipment corrosion, contaminate residues, and damage the environment. The need to neutralize the samples once treated and the consequent increases in the overall cost of the operation is also among the disadvantages associated with the application of concentrated reagents (Duarte et al., 2009; Zu et al., 2014; Günerken et al., 2015).

The acid-based method commonly employs sulfuric acid and hydrochloric acid in concentrations ranging from 1 to $10 \%$ at temperatures between $60-180{ }^{\circ} \mathrm{C}$. It promotes the degradation of cellulose matrix contained in the cell wall, depolymerization of hemicellulose, and hydrolysis of starch into simple molecules in order to avoid the enzymatic hydrolysis step (Harun and Danquah, 2011b; Miranda et al., 2012). The alkaline-based method mainly uses sodium hydroxide. This method is characterized by creating solvation and saponification reactions, forming pores in the cell wall thereby allowing the intracellular compounds to get out of the cell, decreasing the size of the starch polymers as well as the crystallinity of cellulose and starch (Brienzo et al., 2010; Harun et al., 2011c; Sui et al., 2012).

\subsection{Ultrasound pretreatment}

Ultrasound technology has been widely used in the field of organic chemistry for the acceleration of chemical reactions and for the extraction of bioactive compounds from various plant species. The ultrasound process involves the use of sound waves that travel through a liquid medium and creates areas of compression and rarefaction, where pressure changes occurs creating the cavitation phenomenon inducing the formation of bubbles in the elastic medium (Cervantes-Cisneros et al., 2015). Meanwhile, gas that cannot be retained in the bubbles is condensate, releasing a large amount of energy causing a violent collapse of the bubbles creating shock waves and regions of very high temperature and pressure. In fact, the cavitation process is effective on heat and mass transfer, creating hot spots that can cause the acceleration of chemical reactivity in the medium (Picó, 2013). This type of technology can help break the cell wall of microalgae because when bubbles collapse on the surface of a solid, the pressure and elevated temperature create microjets that allow the solvent to penetrate into the raw material and a rupture of the cell wall occurs (Luo et al., 2014). In a previous work reported by Jeon et al. (2013), Scenedesmus obliquus biomass was submitted to ultrasound treatment between $10-60$ min to facilitate the accessibility of bacteria to ferment the sugars present intracellularly in the biomass, with best pretreatment found within a time 
period of $15 \mathrm{~min}$. This pretreatment method is an alternative for cell disruption where water, acid, or alkalis could be used as catalysts for cell wall disruption of microalgal biomass. Ferreira et al. (2016) successfully extracted some compounds (carbohydrates, lipids, proteins, and pigments) within the biorefinery concept from diverse types of microalgae such as C. vulgaris, Nannochloropsis oculata, and S. obliquus, employing low frequency ultrasound and different solvents.

The use of ultrasound also offers the opportunity to modify and improve some important features of bioactive compounds without removing their biological properties (Jambrak et al., 2010). For instance, in third generation bioethanol production, the starch present in microalgae can be modified leading to improvements in the subsequent enzymatic hydrolysis. The effect of ultrasound pretreatment is shown through the distortion of the crystalline regions and improvements in the water uptake of the starch granules, which might aid in the accessibility of the enzymes which could consequently lead to a more efficient hydrolysis process of the carbohydrates (Zheng et al., 2013).

\subsection{Microwave pretreatment}

This type of pretreatment is also used in a large part in the organic chemistry for the acceleration of reactions and extraction of compounds, and it has already been used in the pretreatment of lignocellulosic residues to produce second generation bioethanol and high value compounds in a study carried out by Velazquez-Lucio et al. (2015). The action of this alternative energy is through the interaction with the polar molecules of the solvent, generally water, which form hot nuclei allowing very efficient and rapid heating. Consequently, the reactions could be carried out more quickly, with better yields and greater selectivity (Wang and Lu, 2013; Aguilar-Reynosa et al., 2017). This heating is performed by two mechanisms: 1) by the rotation of the dipoles where the polar molecules try to align in the electromagnetic field that changes rapidly by the microwaves and 2) by the ionic conduction consisting of the instant superheating of the ionic substance due to the friction of the ionic molecules generated by the movement that produces the electric field (Sarker and Nahar, 2012). With the application of microwave irradiation in starch, the native crystallinity of the starch granules is lost and a completely amorphous material is created, i.e., the granule is practically destroyed (Rozzi and Singh, 2000; Sjöqvist and Gatenholm, 2005). Microwave pretreatment promotes starch digestibility which can enhance, depending on the conditions of the pretreatment, the accessibility of enzymes to the pretreated substrate (Emami et al., 2012). Ma et al. (2014) reported the use of microwave pretreatment on Chlorella sp. biomass using 2,450 MHz; $530 \mathrm{~W}$; during 45 and $75 \mathrm{~s}$ as pretreatment conditions and obtained up to $82 \%$ cellular rupture. In a different research work, Ali and Watson (2016) applied the microwave pre-treatment at $943 \mathrm{~W}$ for $5 \mathrm{~min}$ in $N$. oculata and claimed $70 \%$ cell wall destruction. Overall, since microalgae are grown in water and given the ionic nature of water, microwave radiation is well absorbed by the medium and consequently, it is an efficient and rapid way to carry out the pretreatment.

\subsection{Pulse electric field pretreatment (PEF)}

The PEF pretreatment method is a simple technique based on electricity; it is non-thermal and is performed within a short time duration ranging from nanoseconds to milliseconds but at great amplitude from $100-300 \mathrm{~V} \mathrm{~cm}^{-1}$ to $300 \mathrm{kV} \mathrm{cm}^{-1}$. This pretreatment works well both at low and high cell concentrations in liquid and therefore, could be used directly with the microalgal culture. During this treatment, an effect called electroporation or electropermeabilization occurs. In fact, the electric field created induces a power differential through the cellular membrane and electroporation occurs when a certain threshold value is exceeded (between $0.5-1.5 \mathrm{~V}$ ) (Goettel et al., 2013; Vorobiev and Lebovka, 2015). When electroporation occurs, the permeability of cell membrane increases. Cell membranes are mostly negatively charged and are formed by ions and different proteins. In this site, a transmembrane potential exists due to internal and external ionic gradients, and when an external electric field above the said potential is applied, a remarkable cellular polarity will be induced, creating a charge separation and producing a dipole moment that is parallel to the external field (Sheng et al., 2011; Zbinden et al., 2013).

When a critical electric field is applied, the electric forces cause a dielectric break that increases the permeability together with the formation of pores that are usually irreversible. Parniakov et al. (2015) reported the successful use of
$\mathrm{PEF}$ and different $\mathrm{pH}$ values for extracting different compounds such as carbohydrates, proteins, and pigments from the microalgae Nannochloropsis. Recent reports have claimed that the use of hot liquid at temperatures between $20-80{ }^{\circ} \mathrm{C}$ during the electroporation process could increase the effect of the pretreatment on the cellular membrane (Vorobiev and Lebovka, 2015; Postma et al., 2016). Han et al. (2009) studied the effect of the electric pulses on corn starch and observed that by increasing the strength of the pulses they managed to decrease the temperature and enthalpy of gelatinization. Moreover, after the pretreatment with PEF, the starch lost its granule form and its crystallinity level was decreased. Such findings could be indicative of the effectiveness of this technique using microalgae biomass as well. Nonetheless, to the best of our knowledge, the extraction of compounds using this technology has not been thoroughly studied, and this represents a great opportunity for performing further studies with a focus on PEF-based pretreatment of not only microalgae biomass, but also the other types of renewable biomass in order to extract sugars and high added value compounds without damaging or degrading the raw materials used.

\subsection{Mechanical methods}

Conventional mechanical methods are the most used techniques in the industry, offering favorable outcomes at large scale as well as high recovery of the targeted products. Among them, high-pressure homogenization, hydrodynamic cavitation, bead milling and ball milling are mostly in use The homogenization by high pressure works based on a simple principle and could lead to considerable cellular disruption of the biomass. More specifically, cells are placed in a suspension and are displaced and directed by a pump to an orifice with especially designed valves to resist pressure. Subsequently, the flow rate is rapidly increased and the pressure of the fluid decreases over a short distance as it exits the system. Overall, cell disruption by high pressure homogenization is attributed to different causes or mechanisms such as fluid shear, turbulence, shock velocity, and cavitation (Spiden et al., 2013; Yap et al., 2015; Xie et al., 2016).

An alternative form of this technique has also emerged namely hydrodynamic cavitation, generated by passing a liquid or slurry into a large transverse cavity directed to a very small cavity called a throttle valve which causes the constriction of the suspension. This process produces a pressure drop when it falls below the vapor pressure forming microbubbles that collapse when the pressure returns above the normal vapor pressure values. This collapse produces shock waves and increases the pressure and temperature which ultimately results in cell disruption (Lee and Han, 2015).

The two mechanical pretreatment processes most used in the industry in batch or continuous mode for grinding of minerals, ceramics, powders, among other compounds, are the bead mill and the ball mill. In the field of biotechnology, these technologies have already been used for cellular disruption of some microorganisms and are affected by different parameters such as feed rate of the cell suspension, agitation speed, agitator design, diameter and size of the balls, as well as design of the grinding chamber. Besides biomass concentration, density of the suspension, and microorganism morphology, it is also necessary to take into account the interactions of the equipment with the biomass derived from different microorganisms (Montalescot et al., 2015; Postma et al., 2015). Overall, in spite of the effectiveness of these pretreatments for cellular disruption of microalgae biomass, their main drawback is that they do not directly affect the structure of the intracellular carbohydrates, and therefore, a further step would be needed to modify the starch structure. Moreover, these methods are also very energy-intensive. Hence, future studies are still needed and the results obtained through the combination of these methods with others could possibly promote or limit their application.

\subsection{Freezing / thawing pretreatment}

The mechanism of freezing and thawing pretreatment method is simple, i.e., a slow freezing is carried out at temperatures as low as $10^{\circ} \mathrm{C}$ below the freezing temperatures of water. This promotes the creation of ice crystals, mechanically breaking the cell walls (Yang et al., 2015). Intracellular compounds such as carbohydrates, lipids, proteins, and pigments are released into the medium during thawing, while cell membrane compounds and water soluble organic compounds can also be extracted (Carbonell et 
al., 2006; Ando et al., 2016). This pretreatment can be handled in cycles, i.e., the freeze-thaw process is repeated to increase cell disruption thereby, improving the extraction of carbohydrates or other compounds of interest, which are deeply rooted in cellular organelles. Although this pretreatment has been used only for cell disruption, but a recent study on certain lignocellulosic biomasses (which are more difficult to pretreat compared with microalgae biomass) performed by Smichi et al. (2016) proved it to be an efficient alternative and a promising pretreatment for breaking biomass cells leading to a better accessibility of the contained polysaccharides for enzymatic attack. It should also be noted that this pretreatment does not produce any degradation compounds. Nevertheless, the application of this technology is controversial since it can increase energy consumption and the time required to complete the process. In better words, the main disadvantage of the freezing-hawing pretreatment is the need to perform it for at least $24 \mathrm{~h}$ cycles, which would considerably increase the overall time of the production process.

\section{Enzymatic hydrolysis of carbohydrates in microalgae}

As mentioned earlier, the production of bioethanol from microalgae biomass includes three stages: pretreatment, saccharification, and fermentation. One of the advantages of the use of microalgae biomass is that in some pretreatment methods, saccharification can be carried out followed by the pretreatment step without having to implement any different equipment or excessive treatment of the sample. Enzymatic hydrolysis (saccharification) is one of the most important steps to obtain essential sugars such as glucose and mannose for the subsequent fermentation and bioethanol production (Harun and Danquah, 2011a; Milano et al., 2016). More specifically, one of the enzymes used is an endo-amylase attacking internal $\alpha-1-4$ glycosidic bonds of starch producing dextrins. Then, the enzyme amyloglucosidase hydrolyzes alpha $\alpha-1-6$ glycosidic bonds, leading to the production of glucose and other sugars such as maltose (Chen et al., 2013; Ometto et al., 2014; Hernández et al., 2015). Other enzymes such as cellulases and hemicellulases can also be used to obtain simple sugars from cell wall and intracellular polysaccharides (cellulose, hemicellulose, etc.), as reported by Mahdy et al. (2015) who used enzymatic cocktails (Celluclast 1.5 L, Viscozyme L, and Pectinex-Ultra SP- L) on C. vulgaris and Scenedesmus sp. obtaining conversion efficiencies as high as $84 \%$ of total sugars.

The enzymatic hydrolysis of the sugars present in microalgae biomass offers many advantages over chemical hydrolysis with acids or alkalis Those include no requirement for expensive equipment (because it is carried out under mild conditions), no generation of degradation products or toxic compounds (that can potentially affect the subsequent fermentation

Table 4.

Comparison of methods used for starch and total carbohydrates determination.

\begin{tabular}{|c|c|c|c|c|c|}
\hline Method & Reagents / Equipment & Determination method & Advantage & Disadvantage & References \\
\hline \multicolumn{6}{|c|}{ Starch } \\
\hline Perchloric acid & $\begin{array}{l}5 \text { - } 10 \mathrm{mg} \text { sample } \\
\text { Ethanol } 80 \%(\mathrm{v} / \mathrm{v}) \\
\mathrm{HClO}_{4} 35 \%(\mathrm{v} / \mathrm{v})\end{array}$ & Anthrone & \multirow{2}{*}{$\begin{array}{l}\text { - Little sample requirement } \\
\text { - Low cost } \\
\text { - Good reproducibility } \\
\text { - Low reagent control and } \\
\text { precautions } \\
\text { - Little sample requirement }\end{array}$} & \multirow{2}{*}{$\begin{array}{l}\text { - Corrosive reagents } \\
\text { - Low specificity } \\
\text { - Probability of human error } \\
\text { - High interference }\end{array}$} & $\begin{array}{l}\text { Rose et al. (1991) } \\
\text { Brányiková et al. (2011) }\end{array}$ \\
\hline Hydrochloric acid & $\begin{array}{l}5-10 \mathrm{mg} \text { sample } \\
\text { Acetone } \\
\text { Ethanol } 80 \%(\mathrm{v} / \mathrm{v}) \\
\mathrm{HCl} 1.1 \%(\mathrm{v} / \mathrm{v})\end{array}$ & Anthrone & & & $\begin{array}{l}\text { Meyer et al. (1988) } \\
\text { Fernandes et al. (2012) }\end{array}$ \\
\hline Enzymatic & $\begin{array}{l}5 \mathrm{mg} \text { sample } \\
\text { Ethanol } 80 \%(\mathrm{v} / \mathrm{v}) \\
\alpha \text {-amylase } \\
\text { Amyloglucosidase } \\
\text { Glucose oxidase/peroxidase }\end{array}$ & Absorbance & $\begin{array}{l}\text { - High specificity } \\
\text { - Established method } \\
\text { - Low interference } \\
\text { - High reproducibility }\end{array}$ & $\begin{array}{l}\text { - High cost } \\
\text { - High reagent control and } \\
\text { precautions requirement }\end{array}$ & Megazyme (2009) \\
\hline
\end{tabular}

Total Carbohydrates

\begin{tabular}{|c|c|c|c|c|c|}
\hline \multirow{6}{*}{ Chemical } & \multirow{6}{*}{$\begin{array}{l}10 \mathrm{mg} \text { sample } \\
\text { Diluted } \mathrm{HClO}_{4} / \mathrm{HCl}\end{array}$} & \multirow{6}{*}{$\begin{array}{l}\text { Anthrone } \\
\text { Phenol-Sulfuric }\end{array}$} & - Little sample requirement & \multirow{6}{*}{$\begin{array}{l}\text { - Corrosive and toxic reagents } \\
\text { - High interference } \\
\text { - Low specificity }\end{array}$} & \multirow{6}{*}{$\begin{array}{l}\text { Fernandes et al. (2012) } \\
\text { Margarites and Costa (2014) }\end{array}$} \\
\hline & & & - Low cost & & \\
\hline & & & - Good reproducibility & & \\
\hline & & & Tor & & \\
\hline & & & $\begin{array}{l}\text { - Low reagent control and } \\
\text { precautions }\end{array}$ & & \\
\hline & & & - Little sample requirement & & \\
\hline
\end{tabular}

$10 \mathrm{mg}$ sample

$\mathrm{H}_{2} \mathrm{O} 10 \mathrm{~mL}$
Mortar / Ultrasound $10 \mathrm{~min}$
or

Freezing/thawing $12 \mathrm{~h}$
Anthrone

Phenol-Sulfuric
- Little sample requirement

- Moderate cost

- Good reproducibility

- Low reagent control and

precautions requirement
- Corrosive and toxic reagents

- High interference

- Low specificity

- Probability of human error
Laboratory of fermentations and Biorefinery Group (2017)*

\begin{tabular}{|c|c|c|c|c|c|}
\hline HPLC & $\begin{array}{l}300 \mathrm{mg} \text { sample } \\
\mathrm{H}_{2} \mathrm{SO}_{4} 72 \%(\mathrm{v} / \mathrm{v}) \\
\text { Column } 87 \mathrm{H} \\
\mathrm{RI} \text { detector } \\
\mathrm{H}_{2} \mathrm{SO}_{4} 0.025 \mathrm{M} / 0.005 \mathrm{M} \\
0.6 \mathrm{~mL} / \mathrm{min} \text { flow; } 50{ }^{\circ} \mathrm{C}\end{array}$ & HPLC & $\begin{array}{l}\text { - Little sample requirement } \\
\text { - High specificity } \\
\text { - High reproducibility } \\
\text { - Environmental friendly residues }\end{array}$ & $\begin{array}{l}\text { - High cost } \\
\text { - Specific equipment } \\
\text { requirement } \\
\text { - High precaution with } \\
\text { corrosive reagent }\end{array}$ & NREL (2008) \\
\hline
\end{tabular}

Please cite this article as: Velazquez-Lucio J., Colla L.M., Rodríguez-Jasso R.M., Sáenz-Galindo A., Cervantes-Cisneros D.E., Aguilar C.N., Fernandes B.D., Ruiz H.A. Microalgal biomass pretreatment for bioethanol production: a review. Biofuel Research Journal 17 (2018) 780-791. DOI: 10.18331/BRJ2018.5.1.5 
and bioethanol production), and finally higher yields of simple carbohydrates.

\section{Starch and total carbohydrates determination methods}

The main polysaccharide found in microalgae biomass which is used for third generation bioethanol production is starch, and therefore, it is fundamental to know the different techniques used for the quantification of this compound. This section describes some techniques used for the determination of starch as well as the methods used for the quantification of total carbohydrates.

\subsection{Starch determination methods}

As reported by Fernandes et al. (2012), there are different approaches for the determination of starch in microalgae: i) perchloric acid method - in this method, first, interfering compounds (pigments, soluble sugars, and lipids) are extracted with acetone or ethanol, then microalgae starch is extracted and solubilized with perchloric acid, and finally, total sugars are quantified by colorimetric Anthrone method (Rose et al., 1991; Brányiková et al., 2011); ii) hydrochloric acid method - in this method, interfering compounds are first extracted with acetone followed by an ethanolic extraction to ensure complete removal of these substances. After obtaining the starch extract, it will be hydrolyzed by hydrochloric acid followed by total sugars determination by the Anthrone method (Meyer et al., 1988). Finally, iii) enzymatic method - this method is based on enzymatic degradation of starch to glucose with $\alpha$-amylase and amyloglucosidase and it is performed by total starch assay described by Megazyme (2009), endorsed by Association of Analytical Communities (Official Method 996.11) and American Association of Cereal Chemists (Method 76.13). As in the previous methods, in order to extract interfering compounds, the previously ground biomass is incubated in a water bath, followed by the addition of a thermostable $\alpha$-amylase with $\mathrm{pH}$ 7.0. Subsequently, amyloglucosidase with $\mathrm{pH} 4.5$ is added and finally glucose oxidase, peroxidase, and 4-aminoantipyrine (GOPOD reagent) are added to the sample and the mixture is incubated. The absorbance of the sample is measured at $510 \mathrm{~nm}$ by a spectrophotometer using a blank solution (water), GOPOD reagent, and a control sample (D-glucose). Table 4 shows a comparison between starch and total carbohydrate determination methods, including their advantages and disadvantages.

\subsection{Determination methods for total carbohydrates}

Total carbohydrates in microalgae biomass have been determined by diverse colorimetric methods. For all these methods, it is first necessary to break microalgae cells either by using chemical or physical methods. i) chemical methods: these can be used as in the cases of starch quantification methods previously mentioned (see Section 5.1) (Fernandes et al., 2012; Margarites and Costa, 2014). Physical methods: these include grinding with mortar or ultrasound probe (where the sample is subjected to these treatments for around $10 \mathrm{~min}$ ) and freezing/thawing in $12 \mathrm{~h}$ cycles in the presence of water as solvent. The resulting extract obtained through chemical or physical methods is then used for the quantification of total carbohydrates by the phenol-sulfuric method (Dubois et al., 1956) or Anthrone method (Dreywood, 1946). iii) Highperformance liquid chromatography (HPLC)-based total carbohydrate determination: this method is based on the analytical procedures of the National Laboratory of Renewable Energy - USA (NREL, 2008). Briefly, microalgae biomass sample should firs be prepared by concentrated acid hydrolysis. Moe specifically, $\mathrm{H}_{2} \mathrm{SO}_{4}(72 \% \mathrm{w} / \mathrm{w})$ is added into dry biomass in a test tube and the mixture is left for $1 \mathrm{~h}$ at $30^{\circ} \mathrm{C}$ to react. The sample is then diluted to $4 \%$ with distilled water and autoclaved at $121{ }^{\circ} \mathrm{C}$ for $1 \mathrm{~h}$. Subsequently, the solid and liquid fractions are separated and the liquid fraction is used for the HPLC determination in which an ion-exclusion column such as Bio-Rad HPX-87H or Agilent MetaCarb $87 \mathrm{H}$ is required in conjunction with a refractive index detector. The following HPLC conditions can be used to perform the analysis; $\mathrm{H}_{2} \mathrm{SO}_{4} 0.025 \mathrm{M}$ or $0.005 \mathrm{M}$ as mobile phase with a flow ratio between 0.5 to $0.6 \mathrm{~mL} / \mathrm{min}$ and $50^{\circ} \mathrm{C}$ column temperature. Among the carbohydrates that can be quantified with this method are glucose, xylose, cellobiose, arabinose, as well as different byproducts including oxalic, formic, acetic, butyric, succinic and levulinic acids (Juárez et al., 2016).

\section{Conclusions and future prospects}

The extraction of carbohydrates from microalgae biomass is essential to produce third generation bioethanol and the efficiency of this process is dependent on distinct factors, such as morphology (cell wall composition) and algae species. Depending on these characteristics, it is possible to choose the most appropriate pretreatment for a certain type of algal to be used. In the production of bioethanol from microalgae and to make this process viable, it is important to take into account other aspects, such as improving the culture conditions to enhance the accumulation of different compounds of interest (e.g., carbohydrates, lipids, proteins, pigments, etc.), application of the culture water in the pretreatment, and the use of solvents or catalysts that are environmentally friendly. The use of algal biomass in the concept of integrated biorefinery should also be considered, taking advantage of all the compounds present in the biomass and in order to avoid the generation of waste streams.

\section{Acknowledgments}

Financial support from the Energy Sustainability Fund 2014-05 (CONACYT-SENER), Mexican Centre for Innovation in Bioenergy (Cemie-Bio), Cluster of Bioalcohols (Ref. 249564) is gratefully acknowledged. We also gratefully acknowledge the support provided for this research by the Mexican Science and Technology Council (CONACYT, Mexico) through the infrastructure project - INFR201601 (Ref. 269461) and CB-2015-01 (Ref. 254808). The authors Jesús Velazquez-Lucio and Daniela E. Cervantes-Cisneros extent their appreciations to the National Council for Science and Technology (CONACYT, Mexico) for Master fellowship grant support (Grant Number: $711238 / 582371)$.

\section{References}

[1] Aguilar-Reynosa, A., Romaní, A., Rodríguez-Jasso, R.M., Aguilar, C.N., Garrote, G., Ruiz, H.A., 2017. Microwave heating processing as alternative of pretreatment in second-generation biorefinery: an overview. Energy Convers. Manag. 136, 50-65.

[2] Alaswad, A., Dassisti, M., Prescott, T., Olabi, A.G., 2015 Technologies and developments of third generation biofuel production. Renew. Sust. Energy Rev. 51, 1446-1460.

[3] Ali, M., Watson, I.A., 2016. Microwave, thermolysis and lipid recovery from dried microalgae powder for biodiesel production. Energy Technol. 4(2), 319-330.

[4] Ando, Y., Maeda, Y., Mizutani, K., Wakatsuki, N., Hagiwara, S., Nabetani, H., 2016. Impact of blanching and freeze-thaw pretreatment on drying rate of carrot roots in relation to changes in cell membrane function and cell wall structure. LWT Food Sci. Technol. 71, 40-46.

[5] Baroukh, C., Muñoz-Tamayo, R., Bernard, O., Steyer, J.P., 2015. Mathematical modeling of unicellular microalgae and cyanobacteria metabolism for biofuel production. Curr. Opin. Biotechnol. 33, 198205.

[6] Borines, M.G., de Leon, R.L., Cuello, J.L., 2013. Bioethanol production from the macroalgae Sargassum spp. Bioresour. Technol. $138,22-29$

[7] Brányiková, I., Marsálkova, B., Doucha, J., Brányik, T., Bisová, K., Zachleder, V., Vítová, M., 2011. Microalgae-novel highly efficient starch producers. Biotechnol. Bioeng. 108(4), 766-776.

[8] Brienzo, M., Carvalho, W., Milagres, A.M., 2010. Xylooligosaccharides production from alkali-pretreated sugarcane bagasse using xylanases from Thermoascus aurantiacus. Appl. Biochem. Biotechnol. 162(4), 1195-1205.

[9] Carbonel1, S., Oliveira, J.C., Kelly, A.L., 2006. Effect of pretreatments and freezing rate on the firmness of potato tissue after a freeze-thaw cycle. Int. J. Food Sci. Technol. 41(7), 757-767.

[10] Carvalho, A.F.A., de Oliva Neto, P., Da Silva, D.F., Pastore, G.M., 2013. Xylo-oligosaccharides from lignocellulosic materials: chemical structure, health benefits and production by chemical and enzymatic hydrolysis. Food. Res. Int. 51(1), 75-85. 
[11] Castrillón, L.J.R., Carmona, M.E.R., Salazar, Y.V., 2013. Microalgas para la industria alimenticia. Editorial Universidad Pontificia Bolivariana. Colombia.

[12] Castro, Y.A., Ellis, J.T., Miller, C.D., Sims, R.C., 2015. Optimization of wastewater microalgae saccharification using dilute acid hydrolysis for acetone, butanol, and ethanol fermentation. Appl. Energy. 140, 14-19.

[13] Cervantes-Cisneros, D.E., Ruiz, H.A., Aguilar, C.N., Galindo, A.S., Rodríguez-Jasso, R.M., 2015. Evaluación del perfil de compuestos bioactivos de Macrocystis pyryfera extraíos por microondas y ultrasonido. Biorefinery Group, Food Research Department, Faculty of Chemical Sciences, Autonomous University of Coahuila Undergraduate Thesis (In Spanish).

[14] Chen, C.Y., Zhao, X.Q., Yen, H.W., Ho, S.H., Cheng, C.L., Lee, D.J., Bai, F.W., Chang, J.S., 2013. Microalgae-based carbohydrates for biofuel production. Biochem. Eng. J. 78, 1-10.

[15] Chen, W.H., Huang, M.Y., Chang, J.S., Chen, C.Y., 2014. Thermal decomposition dynamics and severity of microalgae residues in torrefaction. Bioresour. Technol. 169, 258-264.

[16] Chen, W.H., Lin, B.J., Huang, M.Y., Chang, J.S., 2015. Thermochemical conversion of microalgal biomass into biofuels: a review. Bioresour. Technol. 184, 314-327.

[17] Chen, W.H., Wu, Z.Y., Chang, J.S., 2014. Isothermal and non-isothermal torrefaction characteristics and kinetics of microalga Scenedesmus obliquus CNW-N. Bioresour. Technol. 155, 245-251.

[18] Cheng, J., Huang, R., Yu, T., Li, T., Zhou, J., Cen, K., 2014. Biodiesel production from lipids in wet microalgae with microwave irradiation and bio-crude production from algal residue through hydrothermal liquefaction. Bioresour. Technol. 151, 415-418.

[19] Cheng, J., Sun, J., Huang, Y., Feng, J., Zhou, J., Cen, K., 2013. Dynamic microstructures and fractal characterization of cell wall disruption for microwave irradiation-assisted lipid extraction from wet microalgae. Bioresour. Technol. 150, 67-72.

[20] Choi, S.P., Nguyen, M.T., Sim, S.J., 2010. Enzymatic pretreatment of Chlamydomonas reinhardtii biomass for ethanol production. Bioresour. Technol. 101(14). 5330-5336.

[21] Cuellar-Bermudez, S.P., Garcia-Perez, J.S., Rittmann, B.E., ParraSaldivar, R., 2015. Photosynthetic bioenergy utilizing $\mathrm{CO}_{2}$ : an approach on flue gases utilization for third generation biofuels. J. Cleaner Prod. 98, 53-65.

[22] Cyanotech Corp, 2016. USA

[23] de Farias Silva, C.E., Bertucco, A., 2016. Bioethanol from microalgae and cyanobacteria: a review and technological outlook. Process Biochem. 51(11), 1833-1842

[24] de Vries, S.C., van de Ven, G.W.J., van Ittersum, M.K., 2014. First or second generation biofuel crops in Brandenburg, Germany? a modelbased comparison of their production-ecological sustainability. Eur. J. Agron. 52, 166-179.

[25] Demuez, M., Mahdy, A., Tomás-Pejó, E., González-Fernández, C., Ballesteros, M., 2015. Enzymatic cell disruption of microalgae biomass in biorefinery processes. Biotechnol. Bioeng. 112(10), 1955-1966.

[26] DEO: Department of Energy, 2016. Alternative Fuels Data Center. USA.

[27] Dreywood, R., 1946. Qualitative test for carbohydrate material. Ind. Eng. Chem. Anal. Ed. 18(8), 499-499.

[28] Duarte, L.C., Silva-Fernandes, T., Carvalheiro, F., Gírio, F.M., 2009. Dilute acid hydrolysis of wheat straw oligosaccharides. Appl. Biochem. Biotechnol. 153(1-3), 116.

[29] DuBois, M., Gilles, K.A., Hamilton, J.K., Rebers, P.T., Smith, F., 1956. Colorimetric method for determination of sugars and related substances. Anal. Chem. 28(3), 350-356.

[30] Emami, S., Perera, A., Meda, V., Tyler, R.T., 2012. Effect of microwave treatment on starch digestibility and physico-chemical properties of three barley types. Food Bioprocess Technol. 5(6), 2266-2274.

[31] Fernandes, B., Dragone, G., Abreu, A.P., Geada, P., Teixeira, J., Vicente, A., 2012. Starch determination in Chlorella vulgaris-a comparison between acid and enzymatic methods. J. Appl. Phycol. 24(5), 1203-1208.

[32] Ferreira, A.F., Dias, A.P.S., Silva, C.M., Costa, M., 2016. Effect of low frequency ultrasound on microalgae solvent extraction: analysis of products, energy consumption and emissions. Algal Res. 14, 9-16.
[33] Fu, C.C., Hung, T.C., Chen, J.Y., Su, C.H., Wu, W.T., 2010. Hydrolysis of microalgae cell walls for production of reducing sugar and lipid extraction. Bioresour. Technol. 101(22), 8750-8754.

[34] Gírio, F.M., Fonseca, C., Carvalheiro, F., Duarte, L.C., Marques, S., Bogel-Łukasik, R., 2010. Hemicelluloses for fuel ethanol: a review. Bioresour. Technol. 101(13), 4775-4800.

[35] Goettel, M., Eing, C., Gusbeth, C., Straessner, R., Frey, W., 2013. Pulsed electric field assisted extraction of intracellular valuables from microalgae. Algal Res. 2(4), 401-408.

[36] Günerken, E., Hondt, E.D., Eppink, M.H.M., Garcia-gonzalez, L. Elst, K., Wijffels, R.H., 2015. Cell disruption for microalgae biorefineries. Biotechnol. Adv. 33(2), 243-260.

[37] Han, Z., Zeng, X.A., Zhang, B.S., Yu, S.J., 2009. Effects of pulsed electric fields (PEF) treatment on the properties of corn starch. J. Food Eng. 93(3), 318-323.

[38] Halim, R., Harun, R., Danquah, M.K., Webley, P.A., 2012. Microalgal cell disruption for biofuel development. Appl. Energy. 91(1), 116-121.

[39] Harun, R., Danquah, M.K., 2011 Influence of acid pre-treatment on microalgal biomass for bioethanol production. Process. Biochem. 46(1), 304-309.

[40] Harun, R., Danquah, M.K., 2011. Enzy matic hydrolysis of microalgal biomass for bioethanol production. Chem. Eng. J. 168(3), 1079-1084.

[41] Harun, R., Jason, W.S.Y., Cherrington, T., Danquah, M.K., 2011. Exploring alkaline pre-treatment of microalgal biomass for bioethanol production. Appl. Energy. 88(10), 3464-3467.

[42] Harun, R., Yip, J.W., Thiruvenkadam, S., Ghani, W.A., Cherrington, T., Danquah, M.K., 2014. Algal biomass conversion to bioethanol-a step-by-step assessment. Biotechnol. J. 9(1), 73-86.

[43] Hernández, D., Riaño, B., Coca, M., García-González, M.C., 2015. Saccharification of carbohydrates in microalgal biomass by physical, chemical and enzymatic pre-treatments as a previous step for bioethanol production. Chem. Eng. J. 262, 939-945.

[44] Ho, S.H., Huang, S.W., Chen, C.Y., Hasunuma, T., Kondo, A. Chang, J.S., 2013. Bioethanol production using carbohydrate-rich microalgae biomass as feedstock. Bioresour. Technol. 135, 191-198.

[45] Ho, S.H., Huang, S.W., Chen, C.Y., Hasunuma, T., Kondo, A., Chang, J.S., 2013. Characterization and optimization of carbohydrate production from an indigenous microalga Chlorella vulgaris FSP-E. Bioresour. Technol. 135, 157-165

[46] Hu, Z., Foston, M., Ragauskas, A.J., 2011. Comparative studies on hydrothermal pretreatment and enzymatic saccharification of leaves and internodes of alamo switchgrass. Bioresour. Technol. 102(14), 7224-7228.

[47] Huang, J., Wei, M., Ren, R., Li, H., Liu, S., Yang, D., 2017. Morphological changes of blocklets during the gelatinization processof tapioca starch. Carbohydr. Polym. 163, 324-329.

[48] Jambrak, A.R., Herceg, Z., Šubarić, D., Babić, J., Brnčić, M., Brnčić, S.R., Bosiljkov, T., Čvek, D., Tripalo, B., Gelo, J., 2010. Ultrasound effect on physical properties of corn starch. Carbohydr. Polym. 79(1), 91-100.

[49] Jena, U., Das, K.C., Kastner, J.R., 2011. Effect of operating conditions of thermochemical liquefaction on biocrude production from Spirulina platensis. Bioresour. Technol. 102(10), 6221-6229.

[50] Jeon, B.H., Choi, J,A., Kimm, H.C., Hwangm, J.H., Abou-Shanab R.A.I., Dempsey, B.A., Regan, J.M., Kim, J.R., 2013. Ultrasonic disintegration of microalgal biomass and consequent improvement of bioaccessibility/bioavailability in microbial fermentation Biotechnol. Biofuels. 6(1), 37.

[51] John, R.P., Anisha, G.S., Nampoothiri, K.M., Pandey, A., 2011. Micro and macroalgal biomass: a renewable source for bioethanol. Bioresour. Technol. 102(1), 186-193.

[52] Juárez, J.M., Hernando, A.L., Torre, R.M., Lanza, S.B., Rodriguez, S.B., 2016. Saccharification of microalgae biomass obtained from wastewater treatment by enzymatic hydrolysis. Effect of alkalineperoxide pretreatment. Bioresour. Technol. 218, 265-271.

[53] Kee, L.M., Teong, L.K., 2015. Bioethanol production from microalgae, in: Kim, S.K. (Eds.), Handbook of marine microalgae. Biotechnol. Advannces, South Korea, pp. 197-208. 
[54] Kim, K.H., Choi, I.S., Kim, H.M., Wi, S.G., Bae, H.J., 2014. Bioethanol production from the nutrient stress-induced microalga Chlorella vulgaris by enzymatic hydrolysis and immobilized yeast fermentation. Bioresour. Technol. 153, 47-54.

[55] Klöck, G., 2010. Internet Directory of the Microalgae Industry.

[56] Kuakpetoon, D., Wang, Y.J., 2007. Internal structure and physicochemical properties of corn starches as revealed by chemical surface gelatinization. Carbohydr. Res. 342(15), 2253-2263.

[57] Laurens, L.M., Dempster, T.A., Jones, H.D., Wolfrum, E.J., Van Wychen, S., McAllister, J.S., Recenberger, M., Parchert, K.J., Gloe, L.M., 2012. Algal biomass constituent analysis: method uncertainties and investigation of the underlying measuring chemistries. Anal. Chem. 84(4), 1879-1887

[58] Lee, I., Han, J.I., 2015. Simultaneous treatment (cell disruption and lipid extraction) of wet microalgae using hydrodynamic cavitation for enhancing the lipid yield. Bioresour. Technol. 186, 246-251.

[59] Lee, O.K., Kim, A.L., Seong, D.H., Lee, C.G., Jung, Y.T., Lee, J.W., Lee, E.Y., 2013. Chemo-enzymatic saccharification and bioethanol fermentation of lipid-extracted residual biomass of the microalga, Dunaliella tertiolecta. Bioresour. Technol. 132, 197-201.

[60] Lenihan, P., Orozco, A., O’Neill, E., Ahmad, M.N.M., Rooney, D.W., Walker, G.M., 2010. Dilute acid hydrolysis of lignocellulosic biomass. Chem. Eng. J. 156(2), 395-403.

[61] Liang, K., Zhang, Q., Cong, W., 2012. Enzyme-assisted aqueous extraction of lipid from microalgae. J. Agric. Food. Chem. 60(47), 11771-11776.

[62] Luo, J., Fang, Z., Smith, R. L., 2014. Ultrasound-enhanced conversion of biomass to biofuels. Prog. Energy Combust. Sci. 41, 56-93.

[63] Ma, Y.A., Cheng, Y.M., Huang, J.W., Jen, J.F., Huang, Y.S., Yu, C.C., 2014. Effects of ultrasonic and microwave pretreatments on lipid extraction of microalgae. Bioprocess. Biosyst. Eng. 37(8), 1543-1549.

[64] Mahdy, A., Mendez, L., Ballesteros, M., González-fernández, C., 2014. Enhanced methane production of Chlorella vulgaris and Chlamydomonas reinhardtii by hydrolytic enzymes addition. Energy Convers. Manag. 85, 551-557.

[65] Mahdy, A., Mendez, L., Tomás-Pejó, E., del Mar, M.M., Ballesteros, M., González-Fernández, C., 2015. Influence of enzymatic hydrolysis on the biochemical methane potential of Chlorella vulgaris and Scenedesmus sp. J. Chem. Technol. Biotechnol. 91(5), 1299-1305.

[66] Margarites, A.C.F., Costa, J.A.V., 2014. Increment of carbohydrate concentration of Chlorella minutissima microalgae for bioethanol production. J. Eng. Res. Ind. Appl. 4(11), 80-86.

[67] Martínez, J.M., Luengo, E., Saldaña, G., Álvarez, I., Raso, J., 2016. Cphycocyanin extraction assisted by pulsed electric field from Artrosphira platensis. Food. Res. Int. 99(3), 1024-1047.

[68] Megazyme Total starch assay procedure (Amyloglucosidase/ $\alpha$-amylase method), 2009.

[69] Mendez, L., Mahdy, A., Demuez, M., Ballesteros, M., GonzálezFernández, C., 2014. Effect of high pressure thermal pretreatment on Chlorella vulgaris biomass: organic matter solubilisation and biochemical methane potential. Fuel. 117, 674-679.

[70] Meyer, J., Schneider, B.U., Werk, K., Oren, R., Schulze, E.D., 1988. Performance of two Picea abies (L.) Karst. stands at different stages of decline. Oecologia. 77(1), 7-13.

[71] Milano, J., Chyuan, H., Masjuki, H.H., Chong, W.T., Kee, M., 2016. Microalgae biofuels as an alternative to fossil fuel for power generation. Renew. Sust. Energy. Rev. 58, 180-197.

[72] Miranda, J.R., Passarinho, P.C., Gouveia, L., 2012. Pre-treatment optimization of Scenedesmus obliquus microalga for bioethanol production. Bioresour. Technol. 104, 342-348.

[73] Montalescot, V., Rinaldi, T., Touchard, R., Jubeau, S., Frappart, M., Jaouen, P., Bourseau, P., Marchal, L., 2015. Optimization of bead milling parameters for the cell disruption of microalgae: process modeling and application to Porphyridium cruentum and Nannochloropsis oculata. Bioresour. Technol. 196, 339-346.

[74] Ometto, F., Quiroga, G., Pšenička, P., Whitton, R., Jefferson, B., Villa, R., 2014. Impacts of microalgae pre-treatments for improved anaerobic digestion: thermal treatment, thermal hydrolysis, ultrasound and enzymatic hydrolysis. Water Res. 65, 350-361.
[75] Orr, V.C.A., Plechkova, N.V., Seddon, K.R., Rehmann, L., 2015. Disruption and wet extraction of the microalgae Chlorella vulgaris using room-temperature ionic liquids. ACS Sustainable Chem. Eng. 4(2), 591-600.

[76] Parniakov, O., Barba, F.J., Grimi, N., Marchal, L., Jubeau, S., Lebovka, N., Vorobiev, E., 2015. Pulsed electric field and $\mathrm{pH}$ assisted selective extraction of intracellular components from microalgae Nannochloropsis. Algal Res. 8, 128-134.

[77] Pasquet, V., Chérouvrier, J.R., Farhat, F., Thiéry, V., Piot, J.M., Bérard, J.B., Kaas, R., Serive, B., Patrice, T., Cadoret, J.P., Picot, L. 2011. Be Study on the microalgal pigments extraction process: performance of microwave assisted extraction. Process Biochem. 46(1), 59-67

[78] Passos, F., Ferrer, I., 2015. Influence of hydrothermal pretreatment on microalgal biomass anaerobic digestion and bioenergy production. Water Res. 68, 364-373.

[79] Picó, Y., 2013. Ultrasound-assisted extraction for food and environmental samples. TrAC, Trends Anal. Chem. 43, 84-99.

[80] Pirwitz, K., Rihko-Struckmann, L., Sundmacher, K., 2016. Valorization of the aqueous phase obtained from hydrothermally treated Dunaliella salina remnant biomass. Bioresour. Technol. 219 , 64-71.

[81] Postma, P.R., Miron, T.L., Olivieri, G., Barbosa, M.J., Wijffels, R.H., Eppink, M.H.M., 2015. Mild disintegration of the green microalgae Chlorella vulgaris using bead milling. Bioresour. Technol. 184, 297 304.

[82] Postma, P.R., Pataro, G., Capitoli, M., Barbosa, M.J., Wijffels, R.H., Eppink, M.H.M., Olivieri, G., Ferrari, G., 2016. Selective extraction of intracellular components from the microalga Chlorella vulgaris by combined pulsed electric field-temperature treatment. Bioresour. Technol. 203, 80-88.

[83] Postma, P.R., Suarez-Garcia, E., Safi, C., Yonathan, K., Olivieri, G., Barbosa, M.J., Wijffels, R.H., Eppik, M.H.M., 2017. Energy efficient bead milling of microalgae: effect of bead size on disintegration and release of proteins and carbohydrates. Bioresour. Technol. 224, 670679.

[84] RFA: Renewable Fuels Association, 2015. Industry Statistics. World Fuel Ethanol Production. USA.

[85] Rose, R., Rose, C.L., Omi, S.K., Forry, K.R., Durall, D.M., Bigg, W.L., 1991. Starch determination by perchloric acid vs enzymes: evaluating the accuracy and precision of six colorimetric methods. J. Agric. Food. Chem. 39(1), 2-11.

[86] Ross, A., Jones, J., Kubacki, M., Bridgeman, T., 2008. Classification of macroalgae as fuel and its thermochemical behaviour. Bioresour. Technol. 99(14), 6494-6504.

[87] Rozzi, N.L., Singh, R.K., 2000. The effect of selected salts on the microwave heating of starch solutions. J. Food Process. Preserv. 24(4), 265-273.

[88] Rubens, P., Heremans, K., 2000. Pressure-temperature gelatinization phase diagram of starch: an in situ fourier transform infrared study. Biopolymers. 54(7), 524-530.

[89] Ruiz, H.A., Rodríguez-Jasso, R.M., Aguedo, M., Kádár, Z., 2015. Hydrothermal pretreatments of macroalgal biomass for biorefineries, in: Prokop, A., Bajpai, R.K., Zappi, M.E. (Eds.), Algal biorefineries. Springer International Publishing, pp. 467-491.

[90] Ruiz, H.A., Rodríguez-Jasso, R.M., Fernandes, B.D., Vicente, A.A., Teixeira, J.A., 2013. Hydrothermal processing, as an alternative for upgrading agriculture residues and marine biomass according to the biorefinery concept: a review. Renew. Sust. Energy. Rev. 21, 35-51.

[91] Ruiz, H.A., Cerqueira, M.A., Silva, H.D., Rodríguez-Jasso, R.M., Vicente, A.A., Teixeira, J.A., 2013. Biorefinery valorization of autohydrolysis wheat straw hemicellulose to be applied in a polymerblend film. Carbohydr. Polym. 92(2), 2154-2162.

[92] Ruiz, H.A., Romaní, A., Michelin, M., Teixeira, J.A., 2013. A importância dos pré-tratamentos no conceito das biorrefinarias. Biotecnologia. 3.

[93] SAGARPA: Secretaría de Agricultura, Ganadería, Desarrollo Rural, Pesca y Alimentación. Generaciones de los biocombustibles, 2011. México. 
[94] Sarker, S.D., Nahar, L., 2012. An Introduction to Natural Products Isolation. Nat. Prod. Isolation. Methods Mol. Biol. 864, 1-25.

[95] Scholz, M.J., Weiss, T.L., Jinkerson, R.E., Jing, J., Roth, R., Goodenough, U., Posewits, M.C., Gerken, H.G., 2014. Ultrastructure and composition of the Nannochloropsis gaditana cell wall. Eukaryotic Cell .13(11), 1450-1464.

[96] Sheng, J., Vannela, R., Rittmann, B.E., 2011. Evaluation of celldisruption effects of pulsed-electric-field treatment of Synechocystis PCC 6803. Environ. Sci. Technol. 45(8), 3795-3802.

[97] Shuping, Z., Yulong, W., Mingde, Y., Chun, L., Junmao, T., 2010. Pyrolysis characteristics and kinetics of the marine microalgae Dunaliella tertiolecta using thermogravimetric analyzer. Bioresour. Technol. 101(1), 359-365.

[98] Sluiter, A., Hames, B., Ruiz, R., Scarlata, C., Sluiter, J., Templeton, D., Crocker, D., 2008. Determination of structural carbohydrates and lignin in biomass. Lab. Anal. Proced. 1617, 1-16.

[99] Smichi, N., Messaoudi, Y., Moujahed, N., Gargouri, M., 2016. Ethanol production from halophyte Juncus maritimus using freezing and thawing biomass pretreatment. Renew. Energy. 85, 1357-1361.

[100] Sjöqvist, M., Gatenholm, P., 2005. The effect of starch composition on structure of foams prepared by microwave treatment. J. Polym. Environ. 13(1), 29-37.

[101] Spiden, E.M., Yap, B.H., Hill, D.R., Kentish, S.E., Scales, P.J., Martin, G.J., 2013. Quantitative evaluation of the ease of rupture of industrially promising microalgae by high pressure homogenization. Bioresour. Technol. 140, 165-171.

[102] Sui, Z., Gizaw, Y., Bemiller, J.N., 2012. Extraction of polysaccharides from a species of Chlorella. Carbohydr. Polym. 90(1), 1-7.

[103] Talebnia, F., Karakashev, D., Angelidaki, I., 2010. Production of bioethanol from wheat straw: an overview on pretreatment, hydrolysis and fermentation. Bioresour. Technol. 101(13), 4744-4753.

[104] Tomaselli, L., 1997. Morphology, ultrastructure and taxonomy of Arthrospira (Spirulina) maxima and Arthrospira (Spirulina) platensis, in: Vonshak, A. (Eds.), Spirulina Platensis Arthrospira: Physiology, cellbiology and biotechnology. Taylor and Francis, USA, pp. 1-18.

[105] Total carbohydrate in microalgae biomass, 2017. Methods standardized by laboratory of fermentations (University of Passo Fundo, Brazil) and biorefinery group (food research department, Autonomous University of Coahuila, México). Results to be published.

[106] van Eijck, J., Batidzirai, B., Faaij, A., 2014. Current and future economic performance of first and second generation biofuels in developing countries. Appl. Energy. 135, 115-141.

[107] Velazquez-Lucio, J., Rodríguez-Jasso, R.M., Galindo, A.S., Contreras, J.C., Cantu, D.J., Ruiz, H.A., 2015. Producción de xilo-oligosacáridos por un proceso hidrotérmico por microondas usando el concepto de biorrefinería integrada. Biorefinery Group, Food Research Department, Faculty of Chemical Sciences, Autonomous University of Coahuila Undergraduate Thesis.
[108] Vorobiev, E., Lebovka, N., 2015. Selective Extraction from Food Plants and Residues by Pulsed Electric Field, in: Chemat, F., Strube, J. (Eds.), Green extraction of natural products: Theory and practice, Wiley-VCH., pp. 307-332.

[109] Wang, K., Brown, R.C., Homsy, S., Martinez, L., Sidhu, S.S., 2013. Fast pyrolysis of microalgae remnants in a fluidized bed reactor for bio-oil and biochar production. Bioresour. Technol. 127, 494-499.

[110] Wang, T.H., Lu, S., 2013. Production of xylooligosaccharide from wheat bran by microwave assisted enzymatic hydrolysis. Food Chem. 138(2-3), 1531-1535.

[111] Xie, Y., Ho, S.H., Chen, C.N.N., Chen, C.Y., Jing, K., Ng, I.S., Chen, J., Chang, J.S., Lu, Y., 2016. Disruption of thermo-tolerant Desmodesmus sp. F51 in high pressure homogenization as a prelude to carotenoids extraction. Biochem. Eng. J. 109, 243-251.

[112] Yaeyama Shokusan Co. Ltd., 2016. Japon.

[113] Yang, C., Liu, W., He, Z., Thangavel, S., Wang, L., Zhou, A., Wang, A., 2015. Freezing/thawing pretreatment coupled with biological process of thermophilic Geobacillus sp. G1: acceleration on waste activated sludge hydrolysis and acidification. Bioresour. Technol. $175,509-516$.

[114] Yap, B.H.J., Dumsday, G.J., Scales, P.J., Martin, G.J.O., 2015. Energy evaluation of algal cell disruption by high pressure homogenisation. Bioresour. Technol. 184, 280-285.

[115] Yuan, T., Li, X., Xiao, S., Guo, Y., Zhou, W., Xu, J., Yuan, Z., 2016. Microalgae pretreatment with liquid hot water to enhance enzymatic hydrolysis efficiency. Bioresour. Technol. 220, 530-536.

[116]Zbinden, M.D.A., Sturm, B.S., Nord, R.D., Carey, W.J., Moore, D., Shinogle, H., Stagg-Williams, S.M., 2013. Pulsed electric field (PEF) as an intensification pretreatment for greener solvent lipid extraction from microalgae. Biotechnol. Bioeng. 110(6), 1605-1615.

[117]Zhao, G., Chen, X., Wang, L., Zhou, S., Feng, H., Chen, W.N., Lau, R., 2013. Ultrasound assisted extraction of carbohydrates from microalgae as feedstock for yeast fermentation. Bioresour. Technol. $128,337-344$.

[118]Zheng, Y., Xiao, R., Roberts, M., 2016. Polymer-enhanced enzymatic microalgal cell disruption for lipid and sugar recovery. Algal Res. 14, $100-108$

[119]Zheng, J., Li, Q., Hu, A., Yang, L., Lu, J., Zhang, X., Lin, Q., 2013. Dual-frequency ultrasound effect on structure and properties of sweet potato starch. Starch J. 65(7-8), 621-627.

[120]Zhou, J., Zhang, F., Meng, H., Bao, G., Zhang, Y., Li, Y., 2014. Development of a silicon carbide disruption method enables efficient extraction of proteins from cyanobacterium Synechocystis sp. PCC 6803. Process Biochem. 49(12), 2199-2202.

[121]Zu, S., Li, W.Z., Zhang, M., Li, Z., Wang, Z., Jameel, H., Chang, H.M., 2014. Pretreatment of corn stover for sugar production using dilute hydrochloric acid followed by lime. Bioresour. Technol. 152, 364-370. 